Vietnam Journal of Mechanics, VAST, Vol. 27, No. 3 (2005), pp. 140-148

\title{
SUSPENDED SAND TRANSPORT IN DIFFERENT CONDITIONS OF TEMPERATURE AND SALINITY
}

\author{
DANG HuU Chung \\ Institute of Mechanics, 264 Doi Can, Hanoi, Vietnam
}

\begin{abstract}
A study on the action of temperature and salinity on the distribution of suspended sand concentration and transport rate has been carried out through a 1DV model with a proposed formula of the kinematic viscosity. Five tests of the data sets from the Delta flume with three different cases of temperature and salinity were used for the simulation. The results of computation showed that the vertical distributions of suspended sand concentration depend on salinity and specially, on temperature. When temperature increases or salinity decreases, the settling process of particles occurs faster. For fine sand, the discrepancy on transport rates due to temperature or salinity decreases with wave height. For coarse sand, the effect of temperature and salinity is not much affected by the wave height. The 1DV model showed good ability to simulate the time-averaged suspended sand concentrations and hence the suspended transport in the ripple regime, provided that the reference concentration near the bed and the vortex-related mixing are represented with sufficient accuracy. Therefore; it can be used effectively to study the behaviour of some physical parameters on the transport.
\end{abstract}

\section{INTRODUCTION}

Up to now the understanding on the mechanism of the vertical suspended sediment as well the exchange between suspended and bed load sediment at the reference level is not well known, especially in the surf zones. So this problem became a great interest for many scientists around the world. The mathematical and physical models for this field are considered as the best choices, because the advantages of numerical solution and measurement are combined. The aim of this paper is to consider the effects of temperature and salinity on the vertical distribution of suspended sand concentration and then the time-averaged suspended sand transport rate under irregular waves. In the surf zone, the suspended sand transport rate comprises two major components, namely the current-related transport component and the wave-related transport component. The current-related transport over rippled beds has been studied in considerable detail (Van Rijn et al., 1993; Van Rijn and Havinga, 1995), but the wave-related transport is less well known. The wave-related transport over a flat bed has been studied in more detail based on numerous experiments in wave flumes (Ribberink, 1998). Recently, the effect of ripple-related sediment mixing has been studied comprehensively on the basis of the 1DV turbulent fluid flow model for irregular waves (Dang Huu Chung and Van Rijn, 2003). The model was calibrated carefully through the comparison with the measured data in the Delta Flume of Delft Hydraulics.

\section{MATHEMATICAL MODEL}

The mathematical model is a modified version of the model presented by Ribberink and Al-Salem (1991 and 1995) by including the effects of irregular waves and vortexrelated mixing. The turbulent fluid movement for (horizontal) uniform flow in the vertical 
plane is considered assuming that the vertical velocity is relatively small compared to the horizontal velocity. Furthermore it is assumed that the region of flow can be divided into an upper and a lower layer, in which the upper layer has no vertical velocity gradient (see Fig. 1). Hence, by using the term of pressure gradient from the equation for the upper layer, the movement in the lower layer is described by the Reynolds' equation as follows (Dang Huu Chung and Van Rijn, 2003):

$$
\frac{\partial u}{\partial t}=\frac{\partial u_{0}}{\partial t}+\frac{\partial}{\partial z}\left(\nu_{t} \frac{\partial \hat{u}}{\partial z}\right), \quad z_{0} \leq z \leq h
$$

in which $u(z, t)=$ horizontal velocity in the oscillatory lower layer, $h=$ depth, $u_{0}=$ horizontal velocity at elevation $z=h=$ transition from lower to upper layer, $t=$ time, $z$ $=$ elevation above bed, $\nu_{t}=$ turbulent viscosity and $z_{0}=$ position of zero velocity.

The initial and boundary conditions used in the model are given in the following:

$$
\begin{gathered}
\left.u(z, t)\right|_{z=h}=f_{1}(t), \\
\left.u(z, t)\right|_{z=z_{0}}=0
\end{gathered}
$$

in which $f_{1}(t)$ is a time series data of irregular wave orbital velocities.

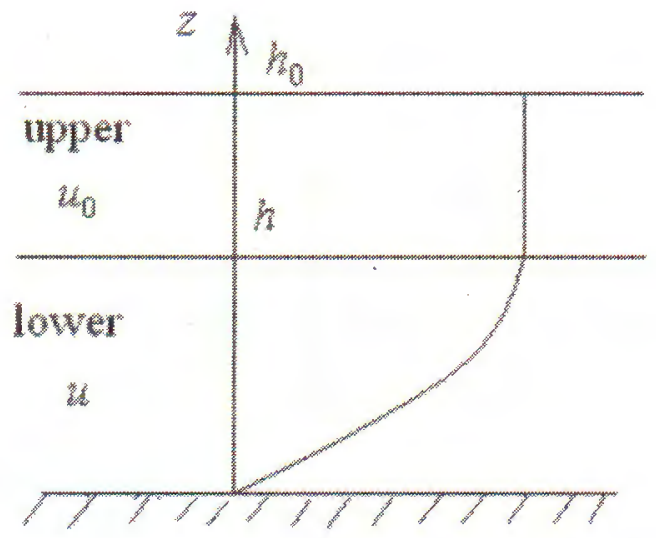

Fig. 1. A sketch of velocity distribution in two-layer region of fluid

Using the same assumptions as for flow equation(2.1), the vertical distribution of sediment concentration is described by the 1DV diffusion equation as follows:

$$
\frac{\partial c}{\partial t}+\frac{\partial}{\partial z}\left(w-w_{s}\right) c=\frac{\partial}{\partial z}\left(\varepsilon_{s} \frac{\partial c}{\partial z}\right), \quad z_{a} \leq z \leq h
$$

in which: $w=0$ = vertical flow velocity, $w_{s}=$ the settling velocity of sediment particle determined by Soulsby (1997), $c=$ volume concentration, $z_{a}=$ reference level, and $\varepsilon_{s}=$ diffusion coefficient for sediment. The reference level is assumed to be equal to the effective bed roughness $\mathrm{k}_{s}$, which is assumed to be equal to the ripple height.

The overall sediment mixing coefficient was modelled as the sum of two components, being the bottom-induced turbulence and the effective vortex-induced mixing:

$$
\varepsilon_{s}=\sqrt{\varepsilon_{s t}^{2}+\varepsilon_{s w}^{2}}
$$


in which $\varepsilon_{s t}, \varepsilon_{s w}$ are the mixing coefficients for sediment due to turbulence and due to vortex motions, respectively. The turbulence-related sediment mixing coefficient is related to the eddy viscosity $\nu_{t}$ and the vortex-induced mixing is due to waves. For details their formulae can be found in Dang Huu Chung and Van Rijn (2003) and the latter is proposed by the authors as follows:

$$
\varepsilon_{s w}=\frac{1}{n} \hat{U} z\left(1-\frac{z}{h}\right)
$$

in which $n$ is the coefficient most likely dependant on grain size and ripple dimensions, $\stackrel{\wedge}{U}$ is the peak orbital velocity.

The initial condition for the sediment diffusion equation is:

$$
\left.c(z, t)\right|_{t=0}=f_{2}(z), \quad z_{a} \leq z \leq h
$$

in which $f_{2}(z)$ is a function derived from measured data.

The boundary condition at $z=h$ :

$$
\varepsilon_{s} \frac{\partial c}{\partial z}=-w_{s} c, \quad z=h
$$

The boundary condition at $z=z_{a}$ :

or

$$
\left.c(z, t)\right|_{z=z_{\alpha}}=c_{a}(t), \text { at } z=z_{a}
$$

$$
\varepsilon_{s} \frac{\partial c}{\partial z}=-w_{s} c_{a}, \text { at } z=z_{a}
$$

in which $c_{a}=$ suspended sand concentration at the reference level and is given from the formula proposed by Dang Huu Chung and Van Rijn (2003):

$$
c_{a}=m \rho_{s} \frac{\left(\theta^{\prime}-\theta_{c r}^{\prime}\right)^{1.5}}{D^{*}}
$$

in which $\theta^{\prime}=$ instantaneous dimensionless bed shear stress related to the grains; $\theta_{c r}^{\prime}=$ critical dimensionless bed shear stress known as Shields parameter; $\rho_{s}=$ density of sediment; $D_{=}^{*}$ dimensionless particle diameter; and $m=$ empirical coefficient related to ripple characteristics and is determined by

$$
m=8.4\left(\frac{r}{\lambda}\right)^{2}-0.7 \frac{r}{\lambda}+0.06
$$

with $r, \lambda=$ ripple height and length respectively:

\section{FORMULA FOR KINEMATIC VISCOSITY}

From equation (2.4) it is observed that the vertical distribution of sand concentration depends on temperature and salinity through the settling velocity of sediment particle, the diffusion coefficient for sediment and the suspended sand concentration at the reference level. Therefore, more general formulas of temperature and salinity for the mathematical model are really necessary.

The experimental data presented by Soulsby (1997) shows that the water density depends very much on temperature and salinity, while the kinematic viscosity nearly does 
not change according to the salinity. Also from the experimental data, the analytic curves for the water density and viscosity were established previously (Fig.2). However, in this paper a new function for the kinematic viscosity is proposed for a better approximation based on the least square method for the hyperbolic behaviour, namely

$$
\nu=\frac{4.43 \cdot 10^{-5}}{23.1+T_{e}},
$$

where is the Celsius temperature. In fact, the formula (13) is only different from the previous one by the values of the coefficients, $(4.4310-5,23.1)$ instead of $(410-5,20)$.

Fig. 2 (Right) shows that the new formula fits quite well the experimental data in the range of temperature from 7 to $350 \mathrm{C}$, while the previous function for the kinematic viscosity shows a less good effect in the ranges of temperature under $7^{0} \mathrm{C}$ and from 14 to $35^{0} \mathrm{C}$.
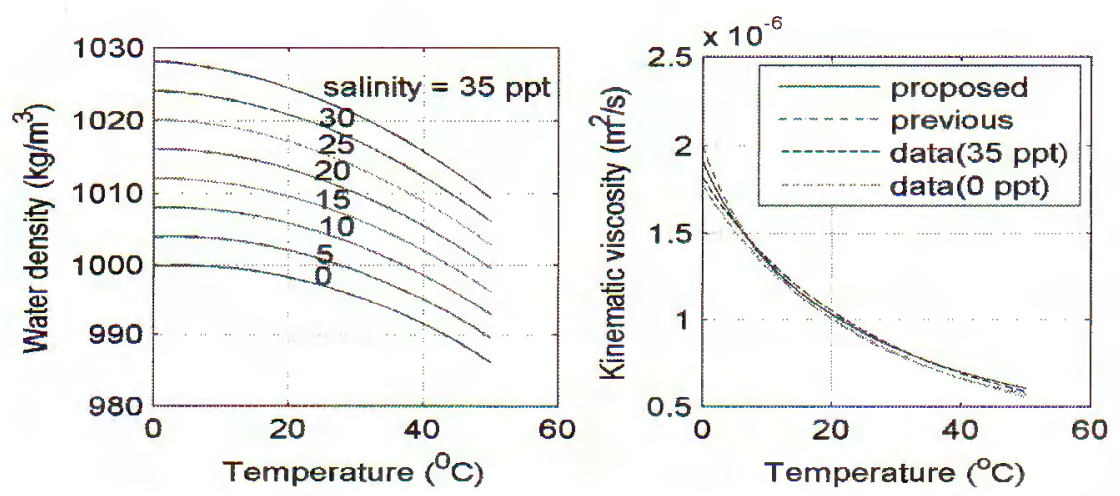

Fig. 2. Left: Water density versus temperature for some values of salinity Right: Kinematic viscosity versus temperature for 2 values of salinity

\section{COMPUTED RESULTS FROM THE MODEL}

The finite difference method with the implicit scheme of Crank-Nicolson was used to solve the equations (2.1)-(2.3) for horizontal velocity and the implicit upwind scheme with a staggered grid for the equations $(2.4),(2.7)-(2.10)$ of the vertical distribution of sediment concentration. The irregular grid was applied to get a better approximation for the changes near bed.

The tests and basic input parameters of the model are given in Table 1, in which typical tests representing five data sets from the different conditions on bed roughness, grain size, wave height and relative steepness of ripples were considered (Dang Huu Chung and Grasmeijer, 1999).

The five tests are in turn computed for three different cases of temperature and salinity, as shown in Table 2. Case T1S1 is used as a standard to evaluate the effect on temperature created by the case T2S1 and the effect on salinity by the case T1S2.

In general, for all cases under consideration the computed instantaneous velocities outside the layer affected by the ripples (roughly two ripple heights above the mean bed; $z>0.1$ to $0.2 \mathrm{~m}$ ) behave quite well in comparison with the measured velocities. Model 
errors mainly occur close to the bed in the vicinity of the ripples $(z<0.1 \mathrm{~m})$ with an acceptable range.

Fig. 3-7 (left) show the computed time-averaged suspended sand concentration profiles with three different cases (T1S1, T2S1 and T1S2) and the comparisons with the measured data. It is seen that the model results of all the tests fit quite well the measurement except the test D1 due to a very strong relative steepness of ripples $r / \lambda$

approx 0.27 . The discrepancies on suspended sand concentrations between the cases T1S1 and T2S1 as well as between T1S1 and T1S2 are presented in Figs. 3-7 on the right. The discrepancies are positive for all five tests and the ones due to temperature are higher than salinity.

Table 1. Input parameters for computations

\begin{tabular}{cccccc}
\hline Test & $\begin{array}{c}\text { Bed } \\
\text { roughness } \\
(\mathrm{m})\end{array}$ & $\begin{array}{c}\text { Grain } \\
\text { size } \\
(\mathrm{mm})\end{array}$ & $\begin{array}{c}\text { Wave } \\
\text { height } \\
(\mathrm{m})\end{array}$ & $\begin{array}{c}\text { Ripple } \\
\text { height } \\
(\mathrm{m})\end{array}$ & $\begin{array}{c}\text { Ripple } \\
\text { length } \\
(\mathrm{m})\end{array}$ \\
\hline $\mathrm{D} 1$ & 0.06 & 0.33 & 1.00 & 0.06 & 0.22 \\
$\mathrm{~B} 2 \mathrm{~A}$ & 0.05 & 0.33 & 1.25 & 0.05 & 0.23 \\
$\mathrm{G} 2$ & 0.03 & 0.16 & 1.00 & 0.03 & 0.72 \\
$\mathrm{H} 3$ & 0.03 & 0.16 & 1.25 & 0.03 & 0.72 \\
$\mathrm{M} 1$ & 0.02 & 0.16 & 1.50 & 0.02 & 0.72 \\
\hline
\end{tabular}

Table 2. Cases for computation

\begin{tabular}{ccc}
\hline Case name & $\begin{array}{r}\text { Temperature } \\
\left({ }^{0} \mathrm{C}\right)\end{array}$ & $\begin{array}{c}\text { Salinity } \\
(\mathrm{ppt})\end{array}$ \\
\hline $\mathrm{T} 1 \mathrm{~S} 1$ & 10 & 35 \\
$\mathrm{~T} 2 \mathrm{~S} 1$ & 20 & 35 \\
$\mathrm{~T} 1 \mathrm{~S} 2$ & 10 & 0 \\
\hline
\end{tabular}

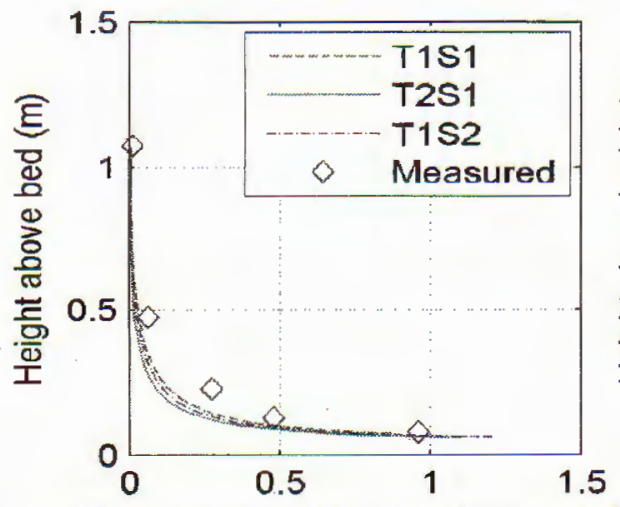

Time-averaged concentration $(\mathrm{g} / \mathrm{l})$

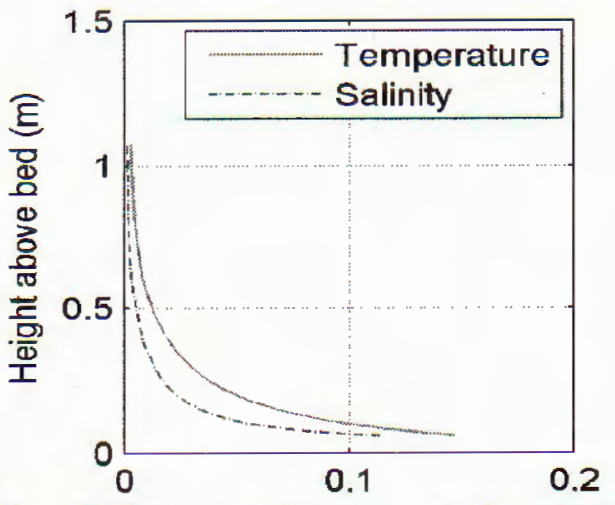

Differences in concentration $(\mathrm{g} / \mathrm{l})$

Fig. 3. Vertical distribution of time-averaged sand concentration (left) for the test B2A and differences in concentration (right) of T2S1 and T1S2 compared to T1S1 

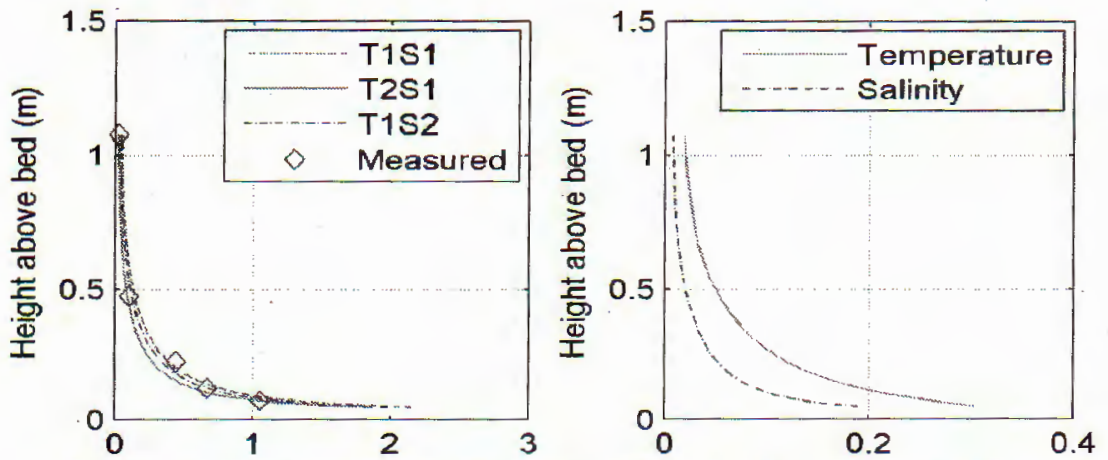

Time-averaged concentration $(g / 1)$

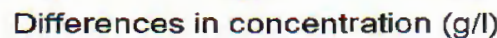

Fig. 4. Vertical distribution of time-averaged sand concentration (left) for the test G2 and differences in concentration (right) of T2S1 and T1S2 compared to T1S1
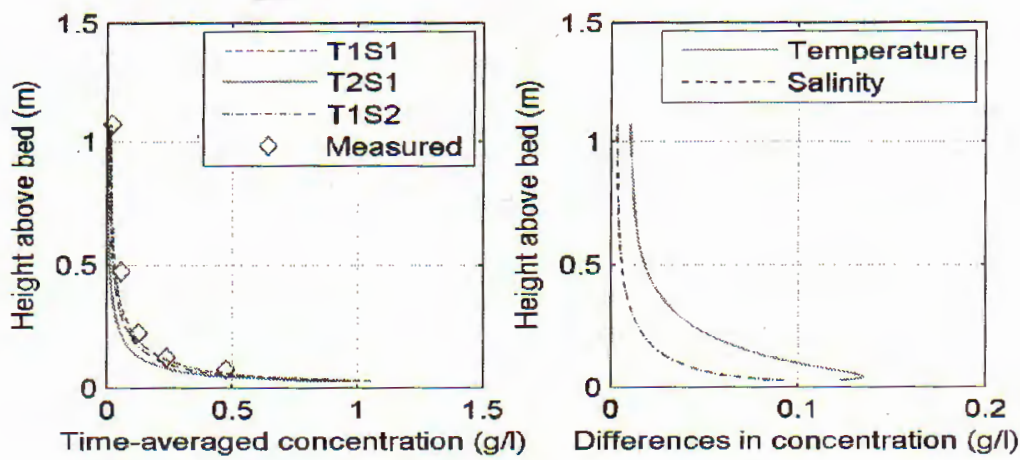

Fig. 5. Vertical distribution of time-averaged sand concentration (left) for the test $\mathrm{H} 3$ and differences in concentration (right) of T2S1 and T1S2 compared to T1S1
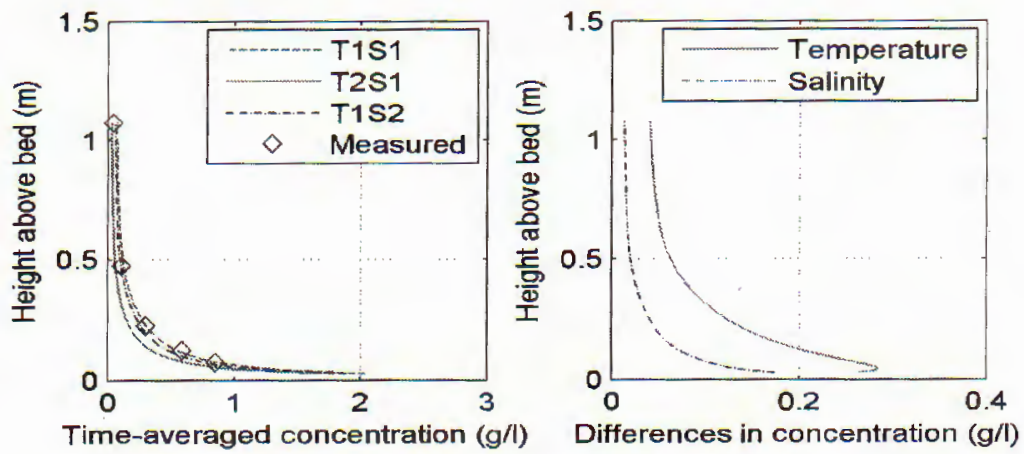

Fig. 6. Vertical distribution of time-averaged sand concentration (left) for the test H3 and differences in concentration (right) of T2S1 and T1S2 compared to T1S1 

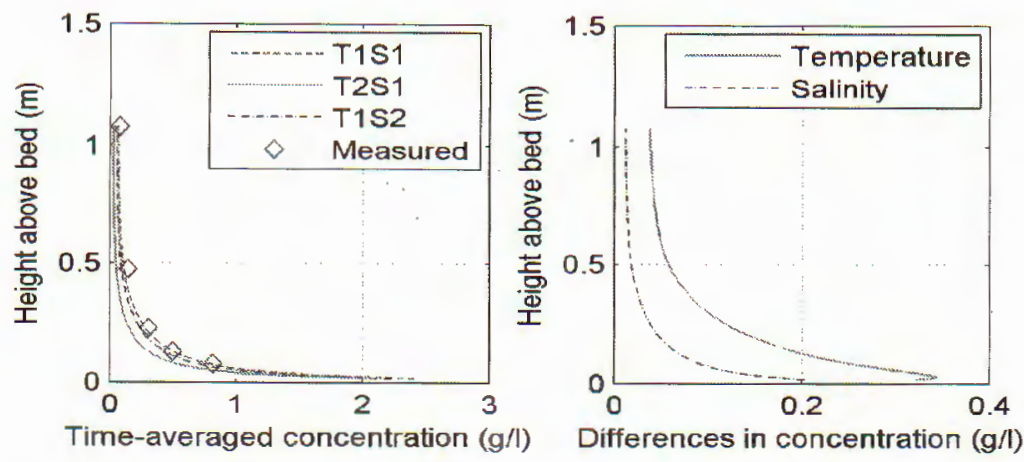

Fig. 7. Vertical distribution of time-averaged sand concentration (left) for the test M1 and differences in concentration (right) of T2S1 and T1S2 compared to T1S1

This can be explained as follows. When the temperature increases or the salinity decreases, the water density and viscosity decrease as well, hence the relative density of the particles increases resulting in an increase of the settling velocity of the particles. Moreover, from Fig. 2 it is seen that viscosity hardly changes with salinity variations and this is the reason why the discrepancies in concentration between T1S1 and T1S2 are smaller than the ones between T1S1 and T2S1. The computations also show that the time-averaged suspended sand transport rates for three different cases of tests D1 and G2 relating to the wave height of $1 \mathrm{~m}$ are much smaller than the others. Moreover, all the test results confirm that the effect of temperature is much stronger than that of salinity. At the same time, it is also found that the discrepancies in transport rates decrease with wave height (between 1 and $1.5 \mathrm{~m}$ ) for fine sand (Tests G2, H3 and M1) due to the dominant effect of wave stirring on the concentrations. For coarse sand (Tests D1 and B2A), the effects of temperature and salinity are not much affected by wave height.

\section{DISCUSSION AND CONCLUSIONS}

In general, a 3D model (such as Dang Huu Chung and Eppel, 2003) will give a more accurate simulation of the flow field for a computation region with a rippled bed. However, it will take more time of computation and becomes quite expensive for such a $3 \mathrm{D}$ model in case of many tests. Moreover, the time-averaged suspended sand concentration profile can be reasonably well simulated, provided that the reference concentration near the bed is modelled with sufficient accuracy and that the vortex-related mixing characteristics are taken into account. In the following some conclusions can be drawn from the study:

1. Temperature and salinity play an important role in the vertical distribution of suspended sand concentration, in which the factor of temperature is stronger. When temperature increases or salinity decreases, the settling velocity as well as the relative density of the particles considerably increases and this speeds up the settling process.

2. The time-averaged suspended sand transport rate decreases with $44 \%$ when temperature increases $100 \%$ and when salinity decreases $100 \%$, then the transport rate decreases about $16 \%$. These comments are really useful for coastal morphodynamics modelling for the different coastal zones, where the temperature and salinity have strong changes.

3. For fine sand, the discrepancy on transport rates due to temperature or salinity decreases with wave height. For coarse sand, the effects of temperature and salinity on the 
transport rates are not much affected by wave height. The physical sense of this situation is still not clear and requires some more tests.

4. The 1DV model showed good ability to simulate the time-averaged suspended sand concentrations and hence the suspended transport in the ripple regime, provided that the reference concentration near the bed and the vortex-related mixing are represented with sufficient accuracy. Therefore, it can be used effectively to study the behaviour of some physical parameters on the transport.

Acknowledgements. This publication completed with financial support from the National Basic Research Program in Natural Sciences. The author would like to thank Prof. Van Rijn for his very useful comments.

\section{REFERENCES}

1. Dang Huu Chung and D. Eppel, Sensitivity of bed morphology within a 3-D numerical model, Proc. 3rd IAHR Symposium on River, Coastal and Estuarine Morphodynamics, Barcelona, 2003, pp. 678-683.

2. Dang Huu Chung and B. T. Grasmeijer, Analysis of sand transport under regular and irregular waves in large-scale wave flume. Report R99-05, IMAU, Utrecht University, the Netherlands, 1999.

3. Dang Huu Chung, B. T. Grasmeijer and L. C. Van Rijn, Wave-related suspended sand transport under irregular waves in ripple regime, Proceedings of Coastal Engineering Conference, Sydney 2000, pp.2836-2849

4. Dang Huu Chung and L. C. VAN'RIJN, Diffusion approach for suspended sand transport under waves, Journal of Coastal Research 19 (1) (2003) 1-11.

5. J. S. Ribberink, Bed-load transport for steady flows and unsteady oscillatory flows, Coastal Engineering 34 (1998) 59-82.

6. J. S. Ribberink and A. Al-Salem, Near-bed sediment transport and suspended sediment concentrations under waves, Proc. Int. Symposium on: "The Transport of Suspended Sediment and its Mathematical Modelling", Florence, Italy, 1991.

7. J. S. Ribberink and A. Al-Salem, 1995. Sheet flow and suspension of sand in oscillatory boundary layers, Coastal Engineering 25 (1995) 205-225.

8. R. Soulsby, Dynamics of Marine Sands, London: Thomas Telford Publications, Thomas Telford Services Ltd, 1997.

9. L. C. Van Rijn et al., Transport of fine sands by currents and waves I, Journal of Waterway, Port, Coastal and Ocean Engineering 119 (2) (1993) 123-143.

10. L. C. Van Rijn and F. J. Havinga, Transport of fine sands by currents and waves II. Journal of Waterway, Port, Coastal and Ocean Engineering 121 (2) (1995) 123-133. 


\section{VẬN TẢI BÙN CÁT LƠ LỬNG TRONG CÁC ĐIỀU KIỆN KHÁC NHAU Vî̀ NHIỆT VÀ MẶN}

Nghiên cứu về sự tác động của các yếu tố nhiệt và mặn đến sự phân bố thẳng đứng nồng độ bùn cát lơ lừng và tốc dộ tải đã được thực hiện thông qua mô hình 1 chiều với công thức hệ số nhớt động học được đề nghị. Số liệu của 5 thí nghiệm trong số nhiều bộ số liệu được đo từ máng sóng của Delft Hydraulics với 3 trường hợp tính khác nhau về nhiệt độ và độ mặn được sư dưng cho việc mô phỏng. Kết quả tính cho thấy rằng sự phân bố thẳng đứng cùa nồng độ bùn cát lơ lựng phụ thuộc vào độ mặn và đặc biệt là nhiêt độ. Khi nhiệt độ tăng hay độ mặn giảm, quá trình lắng của các hạt xáy ra nhanh hơn. Đối với cát mịn, sự chênh lệch về tốc độ tải do tăng nhiệt hay giảm mặn sẽ giảm khi tăng độ cao sóng. Đối với cát thô, hiệu ứng nhiệt mặn tó ra không bị ảnh hương mạnh đối với độ cao sóng. Mô hình một chiều cho thấy có khả năng tốt trong việc mô phởng nồng độ lơ lửng trung bình thời gian và tốc độ tải trong trường hợp đáy gợn sóng, với điều kiện nồng độ bùn cát ở lớp biên sát đáy và các đặc trưng rối được mô tà tốt. Do đó, nó có thể được sứ dụng một cách hiệu quả để nghiên cứu các ứng xự của các tham số vật lý lên quá trình vận tải bùn cát.

Mobile: 0912226480,

Fax: 84-4-8333039,

Email: dhchung@im01.ac.vn 